Dossiê: Judaísmo: religião, cultura, nação - Artigo Original ๑응

\title{
Diálogos e tensões no judaísmo no período helenista
}

\author{
Dialogues and tensions in Judaism of the Hellenistic Age
}

\author{
Solange Maria Carmo * \\ Aíla L. Pinheiro de Andrade **
}

\begin{abstract}
Resumo
$\mathrm{O}$ artigo aborda o conceito, o surgimento e os tipos de diásporas judaicas com enfoque especialmente no período helenista (de 312 a.C. a 31 a.C.). Depois, mostra como a influência helenista foi recebida de forma diferente pelos judeus. Os judeus dispersos, espalhados especialmente pelo Egito, sujeitos ao domínio dos Lágidas, mantiveram um fecundo diálogo com a cultura grega, assimilando-a e aproveitando-a para difundir seus escritos. Em contrapartida, os judeus residentes nas terras de Israel, sujeitos ao domínio dos Selêucidas, da Síria, rejeitaram fortemente a cultura helênica imposta pelos dominadores, pois esta ameaçava a identidade judaica. Do encontro e do confronto das culturas judaica e helênica, surgiu fecunda produção literária, seja de apoio ao helenismo (literatura de justificação) ou de rejeição a ele (literatura de resistência). Breves informações são fornecidas, mostrando a afinidade das obras com a cultura grega ou sua rejeição da mesma. Muitas dessas obras fazem parte do cânon bíblico.
\end{abstract}

Palavras-chave: judaísmo; diáspora; helenismo; literatura de resistência; literatura de justificação.

\begin{abstract}
The article discusses the concept, the emergence and the kind of Jewish Diasporas with emphasis in the Hellenistic Age (from 312 BC to $31 \mathrm{BC}$ ). Then, it demonstrates the different ways in which the Jews received the Hellenistic influence. The Jews who lived in Egypt, and were subject to the dominion of the Ptolemies, maintained dialogue with Greek culture, assimilating it and taking advantage of it to spread his writings. On the other hand, Jews who resided in Israel, subject to the rule of the Seleucids, rejected tightly the Hellenic culture imposed by the dominators, because it threatened the Jewish identity. From the encounter and confrontation of the Jewish and Hellenic cultures enormous range of literary works has emerged, both in defense of Hellenism (justification literature), and rejection of it (literature of resistance). Brief information is given about these two kinds of literature. Some of these writings are in the bible.
\end{abstract}

Keywords: judaism; diaspora; hellenism; literature of resistance; justification literature.

\footnotetext{
Artigo submetido em 11 de março de 2019 e aprovado em 28 de abril de 2019.

* Doutora em teologia pela Faculdade Jesuíta de Filosofia e Teologia - FAJE. Professora da PUC-Minas e do ISTA. País de origem: Brasil. E-mail: carmosolange@gmail.com

** Doutora em Teologia pela Faculdade Jesuíta de Filosofia e Teologia - FAJE. Professora na Faculdade Católica de Fortaleza. País de origem: Brasil. E-mail: aylanj@gmail.com
} 


\section{Introdução}

A permanência dos judeus fora da terra de Israel é designada pelo termo grego diáspora, geralmente traduzido por dispersão. A palavra pertence ao campo semântico agrícola, ou seja, diáspora tem a ver com semeadura, com o ato de espalhar a semente na terra.

Espalhados qual semente no mundo, os judeus se esforçavam para preservar sua identidade, sem se fechar às culturas dos povos estrangeiros. Deviam se integrar na nova sociedade, adaptar-se a ela, mas sem assumir seus costumes e valores, muitas vezes contrários à fé monoteísta dos hebreus (RAINER, 2009, p. 167-191). Esse esforço de manutenção da identidade judaica em tempos de helenismo foi decisivo para que os judeus da diáspora reunissem suas memórias e as colocassem por escrito.

\section{Um pouco de história}

É importante retomar a história do povo hebreu, especialmente a partir do evento do Exílio da Babilônia, quando fizeram sua primeira e mais significativa experiência de se estabelecer fora da terra de seus pais.

É bem verdade que em 722, o Reino do Norte (Israel) já havia passado por experiência semelhante de dispersão. A Assíria dominou a capital Samaria e dispersou os israelitas para diversas partes do mundo onde seu domínio se estabelecera. Além disso, trouxe para a região da Samaria outros povos já subjugados. O convívio com os povos estrangeiros e a assimilação de sua cultura fora imposta a Israel. Por causa disso, e de outras questões políticas, o Reino do Norte não era bem visto pelo reino do Sul, Judá, capital Jerusalém. O povo de Judá acusava os samaritanos de sincretismo, de idolatria e de impureza.

Em torno do ano 587 a.C., foi a vez de Judá (Reino do Sul) passar por uma experiência dolorosa de submissão. A elite do país, a saber, nobres, intelectuais e artífices (2Rs 24,14-16; 25,18-20), foi exilada para a capital do império babilônico 
com o objetivo de impedir qualquer incentivo a rebeliões do povo conquistado (OTZEN, 2003, p. 16). Nabucodonosor, rei da Babilônia, não poupou Jerusalém. Além de deportar aqueles que tinham força para o trabalho, deixou a capital destruída, humilhada e sem condições de se reerguer. Os deportados acharam seu caminho, apesar do exílio forçado. Em terras babilônicas, muitos alcançaram prosperidade e estabilidade econômica. Lá não eram obrigados a trabalhos forçados, como no Egito; ao contrário, levavam uma vida de súditos livres. Podiam possuir casas próprias, plantações e comércios, e não faltou quem conseguisse fazêlo; alguns até chegaram a ocupar cargos administrativos elevados na corte imperial. A Babilônia se transformou no maior e mais ativo centro de judeus fora de sua terra por muito tempo (OTZEN, 2003, p. 17-18).

A partir de 538 a.C., com o domínio persa, Ciro, por meio do edito que levou seu nome, permitiu o retorno dos exilados para a terra de seus antepassados, mas a maioria dos deportados não deixou a Babilônia. Os judeus que se decidiram pelo repatriamento empreenderam a tarefa de preservar a pureza de sua religião, livrando-a da contaminação de elementos do politeísmo. Tal encargo exigia a separação estrita dos judeus de todos os povos estrangeiros (Esd 10,11; Ne 9,2), com o objetivo de cumprir rigorosamente a Lei de Moisés (Esd 7,10.26; Ne 10,29; OTZEN, 2003, p. 18-19).

Depois do retorno, iniciado em 538, a vida não se tornou mais fácil para quem se estabeleceu na Judeia. Alexandre Magno empreendeu uma campanha vitoriosa de dominação e, desde o ano 333 a.C., uniu definitivamente o Oriente com o Ocidente. Além da conquista política, a vitória do Macedônio trouxe outras consequências: a língua grega tornou-se o idioma oficial do império e a cultura, a arte e o pensamento gregos foram impostos aos povos orientais. Mesmo em suas terras, os judeus deveriam conviver com outro povo, outro modo de pensar e de organizar a vida, ou seja, outra gramática existencial simbólica. 
Deu-se, a partir da conquista de Alexandre, a chamada ocidentalização do Oriente. Mas se por um lado ao Oriente fora imposta a cultura grega, por outro também o espírito grego ficou profundamente marcado pelo Oriente. Dessa simbiose entre dois mundos distantes, surgiu uma cultura pseudo-grega, diferente, em muitos aspectos, da cultura da Hélade original. Conforme Otzen a maior importância do império de Alexandre foi "ter criado as bases para um encontro cultural entre o Oriente e o Ocidente [...] Os portões entre Oriente e Ocidente haviam sido abertos de uma vez por todas" (OTZEN, 2003, p. 21). Desde então, o desenvolvimento cultural e religioso do Oriente Médio, que também incluía os judeus, ficou marcado para sempre.

Chevitarese e Cornelli disyinguem helenismo e helenização. Lembram que a expressão "helenismo" ganhou contornos diferentes ao longo da história. Compreendido como o uso gramatical correto da língua grega, ou seja, o grego livre de barbarismos (século IV), helenismo passou a caracterizar a adoção das maneiras gregas, do modo de vida grego, em especial fora da Hélade, onde a cultura grega se tornara moda. Já o termo "helenização", para esses autores, é o processo de adoção e adaptação dessa cultura em nível local (CHEVITARESE; CORNELLI, 2003, p. 7).

Assim, os termos helenismo ou helenista passaram a ser usados para expressar a assimilação que os judeus fizeram do idioma, da cultura e dos costumes gregos, desde o século IV a.C. até os primeiros séculos da era cristã. É nesse contexto de acolhida do mundo helênico que se fala de diáspora judaica no período helenista.

Quando Alexandre morreu, não deixou herdeiros. Seu império, depois de disputas homéricas entre seus generais, foi dividido em quatro reinos: o reino de Cassandro, que era composto pela Macedônia, a maior parte da Grécia e partes da Trácia; o reino de Lisímaco, que incluía a Lídia, a Jônia, a Frígia e outras partes da atual Turquia; o reino de Seleuco, que compreendia o atual Irã, o Iraque, a Síria e partes da Ásia Central; o reino de Ptolomeu I, que incluía o Egito e as regiões adjacentes. A terra dos judeus ficou sob o domínio dos Ptolomeus do Egito, 
também conhecidos como Lágidas ${ }^{1}$, durante o período de 305 a 198 a.C. e, posteriormente, esteve sob a mão de ferro dos Selêucidas da Síria (RAJAK, 2009, p. 64-88).

Com os Lágidas, do Egito, a religião dos judeus estava salvaguardada; os egípcios não implicavam com a religião judaica nem impunham aos judeus o culto politeísta. Mas, com os Selêucidas, da Síria, especialmente com Antíoco IV ou Epífanes, deu-se uma imposição do politeísmo, que obrigava os judeus a algumas práticas consideradas abomináveis pela Torah. Enquanto os judeus dispersos pelo reino dos Lágidas (diáspora helenista), especialmente em Alexandria, gozavam de paz e liberdade; em terras de Israel, o povo na Palestina sofria perseguições, desrespeitos, imposições religiosas, ameaças de todo tipo e até martírio.

\section{A diáspora judaica no período helenista}

A diáspora judaica no período helenista (312 a.C. a 31 a.C.)² não deve, pois, ser confundida com a diáspora oriental, por ocasião do exílio da Babilônia (597 a.C.) e nem com aquela que se desenvolveu mais tarde no período romano, também chamada de diáspora ocidental. Quando falamos em diáspora grega, referimo-nos à incorporação, feita por grande parte dos judeus, do estilo de vida grego, iniciada tecnicamente com a derrota da Pérsia por Alexandre Magno em 333 a.C., mas a influência grega tem raízes mais antigas. Por meio do comércio ambulante das caravanas e dos mercenários gregos que se ingressaram no exército persa, elementos da cultura ocidental foram difundidos no Oriente, muito antes da apoteose de Alexandre.

A influência do helenismo sobre a vida judaica não se deu apenas nos grupos de judeus dispersos, radicados em outras terras do império. A cultura grega se difundiu por aquelas regiões, como mostra o surgimento da decápole, as dez polis, no leste da terra de Israel em lugar de antigas fundações semitas. A decápole se

\footnotetext{
${ }^{1}$ A denominação "lágidas" vem de "Lagus", o pai de Ptolomeu I. Embora a dinastia tenha durado até o ano 30 aC no Egito, na Terra Prometida, durou apenas até o ano 198 aC, quando a região passou para o domínio dos Selêucidas, da Síria.

${ }^{2}$ Em 312 a.C. deu-se início a dominação dos Ptolomeus e em 31 aC começou a dominação romana, sobre as terras de Israel e sobre o Egito.
} 
tornou um centro de irradiação da cultura helênica (OTZEN, 2003, p. 23-25), que se espalhou facilmente por todo canto. Lugares e pessoas receberam nomes helênicos; a organização política ganhou nova configuração; as relações públicas foram repensadas; as artes, as ciências, a transformação de matérias-primas, ou seja, os âmbitos mais comuns da vida e das associações do povo foram afetados pelo pensamento helênico. Essa influência não se limitou à aristocracia; ela se fez presente em todas as camadas da sociedade judaica, embora os aristocratas tenham lucrado mais com essa situação por causa das vantagens resultantes da colaboração com os dominadores estrangeiros.

No Egito, a cidade de Alexandria, fundada em homenagem a Alexandre Magno em 331 a.C., tornou-se um grande centro de aprendizagem e de difusão da cultura grega. Nessa cidade, o judaísmo helênico floresceu em grande escala. Muitos judeus migraram voluntariamente para lá em busca de riqueza ou de desenvolvimento cultural (RAINER, 2009, p. 206-208). Durante o domínio grego ptolomaico sobre os judeus (de 322 a 198 a.C.), efetuado sob o comando da família dos Ptolomeus ou Lágidas, uma grande comunidade judaica foi fundada em Alexandria sem grandes conflitos com os gregos.

Em Alexandria, os judeus contavam com a proteção das leis civis. Não eram cidadãos da polis, nem o desejavam, pois teriam que renunciar à sua identidade judaica. Eles constituíam um grupo distinto; estavam classificados entre os politai e formavam politeuma, o que hoje seria análogo a uma associação civil (OTZEN, 2003, p. 73-74). Apesar de estarem socialmente abaixo dos gregos, os judeus estabelecidos em Alexandria ocupavam um lugar social acima da população egípcia nativa, com garantia de alguns direitos. $\mathrm{O}$ inconveniente dessa situação era ficar à mercê do apoio ou do não reconhecimento por parte de cada monarca. A situação dos judeus em Alexandria carregava um quê de instabilidade; ela os obrigava a uma constante vigilância e exigia-lhes uma habilidade sempre renovada de se fazerem aceitos. Para se estabelecer no Egito, era preciso um esforço constante de diálogo com a cultura reinante, o helenismo. Mesmo assim, embora a maioria dos judeus ali residentes preferisse morar em suas próprias comunidades, os guetos eram 
desconhecidos e a mistura com outras etinias era comum (cf. COHEN, 1999, p. 5662).

Por causa da situação de instabilidade, os judeus de Alexandria procuraram o reconhecimento social através da produção literária com a qual desejavam mostrar seu valor. Assim, ergueram altos voos na filosofia; elaboraram explicações alegóricas, provenientes principalmente do estoicismo, para mostrar o valor de suas Escrituras e de seus antepassados. Nesse conjunto de esforços para se afirmar e arrecadar reconhecimento, surgiu a versão grega das Sagradas Escrituras, a Septuaginta (LXX), que ganhou certo acabamento durante o reinado de Ptolomeu VI, de 181-145 a.C. (DORIVAL, 1988, p. 111). A Septuaginta veio à luz graças a uma necessidade urgente dos judeus helenistas: como não dominavam mais o idioma dos antepassados, era preciso traduzir seus textos fundantes para o grego, a língua do império. Além da tradução das obras hebraicas, que compunham a chamada TaNak, novos livros escritos originalmente em grego foram incorporados à Septuaginta (RAJAK, 2009, p. 222-227). O judaísmo aproveitou-se do fato de que a religião antiga, sendo politeísta, era tolerante com outros pontos de vista religiosos (FELDMAN, 1993, p. 416).

\section{Diálogos e tensões}

A identidade dos judeus na diáspora helenista foi mantida, em grande parte, através da ética e da piedade ou religiosidade judaica (RAINER, 2009, p. 225-227). Enquanto para a maioria dos gentios o pensamento judaico soava como um fenômeno estranho, algumas pessoas simpatizavam com muitos dos códigos éticos da Lei Mosaica. Vários aspectos da Lei encontraram um público receptivo entre os gentios, em parte por causa da decadência moral do culto às divindades helênicas, mas também porque foi se desenvolvendo uma crescente admiração pelo monoteísmo entre os gentios (COLLINS, 1983, p. 6-13). Cohen descobre o início de uma nova identidade judaica como análoga e sob a influência de ideias e instituições helênicas (COHEN, 1999, p. 134-135). 


\subsection{Produção literária de justificação}

A influência que o helenismo exerceu sobre os judeus de Alexandria foi notável e durou muitos séculos. Para dar a conhecer a grandeza de sua cultura, sem nenhum pudor os judeus helenistas fizeram uso do estilo literário e do idioma gregos para narrar sua história e registrar sua sabedoria para a posteridade. No entanto, essa produção literária foi expulsa da ortodoxia judaica por causa do sentimento nacionalista despertado na revolta dos Macabeus durante a dominação selêucida sobre a terra de Israel. Enquanto no Egito as comunidades judaicas rabínicas floresciam e deixavam vestígios culturais em Alexandria, em terras de Israel vivia-se perseguição ferrenha dos Selêucidas, o que gerava rejeição da cultura helênica (OTZEN, 2003, p. 73-74). Para os judeus integristas (nacionalistas) que viviam sob a perseguição dos Selêucidas, o helenismo soava como ameaça e perda da identidade judaica. Era visto como um grande perigo para a juventude, um inimigo a ser combatido. Para os judeus de Alexandria, porém, o helenismo era um aliado, uma via que possibilitava a divulgação da fé monoteísta. Nesse intento, produziram alguns escritos através dos quais explicavam seus costumes e sua religião, de modo a serem aceitos pelos gregos. Ao enfatizar os valores comuns e minimizar as práticas exclusivas do judaísmo, tais como a circuncisão e os rituais de pureza, escritores do universo judeu-helênico argumentavam a favor da universalidade de sua religião. Muitos foram, inclusive, além dos limites de sua própria literatura e imitaram obras famosas de autores gregos no campo da história, da poesia e da filosofia como é o caso, por exemplo, dos escritos sapienciais.

Para a fé judaica, mesmo quando sob a influência grega, a sabedoria não era compreendida como o resultado de mera especulação intelectual. Suas raízes se encontravam na sabedoria divina, ou seja, em Deus mesmo. Para eles, por meio de sua sabedoria, Deus havia ordenado o caos primitivo. Se ela era o princípio ordenador do cosmos, então adquirir sabedoria significava ter as diretrizes para uma vida ordenada em harmonia com toda a criação. 
A palavra hebraica para sabedoria é hokmah e está relacionada a uma raiz que significa "habilidade". O termo sugere "habilidade para viver", bem mais que habilidade para fazer coisas. O sábio, o hakam, era alguém que possuía maturidade ou sabia viver bem. Possuidor desse bem viver, ele deveria transmitir seu conhecimento a outras pessoas (LÍNDEZ, 2011, p. 38-46). As preocupações dos sábios judeus, quase sempre, estavam relacionadas com a vida cotidiana. Seus ensinamentos escapam do mundo sagrado ou religioso e se espalham pelos diversos âmbitos da vida. Em termos gerais, os ensinamentos da sabedoria judaica são práticos em vez de teóricos, universalistas e não nacionalistas, humanistas e não somente religiosos. Apesar de não negligenciar o aspecto religioso, a literatura sapiencial não coloca seu foco na religião, mas na vida, na arte de viver harmonicamente.

Dentre as produções literárias dos judeus helenistas, destacamos abaixo as que mais contribuíram para a propagação da universalidade da fé judaica, chamadas neste artigo de literatura de justificação.

a) Sirácida ou Eclesiástico (NICKELSBURG, 2011, p. 116-138; CERESKO, 2004, p. 130-154).

O livro do Sirácida3 ${ }^{3}$ ou Eclesiástico, aproximadamente do ano 190 a.C., é resultado da tradução grega de uma obra originalmente escrita em hebraico. Nem sempre a literatura da época helenista foi escrita originalmente em grego. Algumas vezes foi escrita em hebraico, sob a influência da cultura grega; é o caso do livro do Sirácida. O prólogo grego, escrito pelo neto do autor, informa que o texto foi traduzido no Egito, provavelmente em 132 a.C., no trigésimo oitavo ano do rei Evergetes ou Ptolomeu VII, que reinou de 170-117 a.C.

Os temas do Sirácida tendem a ser universais e são guias para as relações humanas mais simples. São conselhos que auxiliam os jovens aprendizes em matérias de saúde e de negócios, ensina-os as virtudes da boa convivência como,

\footnotetext{
${ }^{3}$ Sirácida nome com o qual o livro ficou conhecido entre os judeus por causa de seu autor Yeshua ben-Sirach. Entre os cristãos, foi nomeado de Eclesiástico ou livro da Eklesia (Igreja).
} 
por exemplo, manter sigilos $(27,16)$ e evitar a difamação $(28,13 \mathrm{ss})$. Admoesta-os a evitar os vícios e a viver sabiamente. São máximas sapienciais colocadas na boca de um sábio, a fim de assegurar a identidade judaica, problema posto desde a volta do exílio. Percebendo o fascínio da cultura helênica sobre os jovens, o autor exorta-os a permanecerem firmes na fé de seus pais, nos costumes judaicos por eles transmitidos, sem se envergonharem de suas origens e crenças. Assim, sem rejeitar o helenismo, o Sirácida mostra as vantagens da sabedoria judaica.

O livro traz um longo poema de elogio da criação $(42,15-43,37)$ e dos antepassados (44,1-50,31), com o intuito de manter a memória dos pais da fé e mostrar que eles não perdem em nada para os heróis gregos. A começar por Henoc, o autor faz uma ode aos grandes nomes da história de Israel, lembrando figuras como Noé, Abraão, Isaac, Jacó, Moisés, Samuel, Davi, Elias... Mostra seus feitos maravilhosos em favor do povo e a fidelidade dos mesmos aos ensinamentos do Senhor e à aliança com ele estabelecida.

A sabedoria personificada é apresentada como um dom concedido por Deus aos seres humanos $(1,7)$ e, ao mesmo tempo, é mostrada como um atributo divino: origem atemporal e misteriosa, habitação celeste, presença universal, vivificante, e medianeira entre Deus e o cosmos (Eclo 24,5) e entre Deus e a humanidade (Eclo 24,8-10). Em algumas passagens, a sabedoria divina é identificada com a Lei de Moisés (Eclo 1,26; 6,37; 15,12; 19,20).

\section{b) Livro de Tobias (LEVINE, 1992, p. 105-17).}

A narrativa no Livro de Tobias é ambientada no século VIII a.C. No entanto, vários erros históricos descartam a autoria contemporânea àquele período da história, e a maioria dos estudiosos prefere situar a composição de Tobias entre 225 e 175 a.C. O surgimento do livro de Tobias para depois de 175 a.C. é dificilmente sustentada, pois o autor não expressa nenhuma consciência das tentativas dos Selêucidas de helenizarem a Judéia (175 a.C.), nem menciona a Revolta dos Macabeus contra os Selêucidas (165 a.C.), nem adota a apocalíptica ou expectativas messiânicas sobre as quais os escritos dessa época se concentram. 
A língua original da composição permanece obscura. Tobias pode ter sido originalmente composto em aramaico ou hebraico, uma vez que fragmentos de Tobias em ambas as línguas foram descobertos em Qumran. O livro conta a história de Tobit, um israelita justo da tribo de Naftali, que vive em Nínive depois de Sargão II ter deportado as tribos do norte de Israel para a Assíria em 721 a.C.

A narrativa principal é dedicada ao filho de Tobit, Tobias, que é enviado por seu pai para receber um dinheiro que o ancião depositou na distante Média. Raphael se oferece para ajudar e proteger Tobias. Ao final da missão, Rafael revelase como um anjo.

Desenvolvendo temas como a pureza do casamento, a piedade filial e a reverência pelos mortos, o livro mostra que um judeu da diáspora pode ser tão fiel quanto um repatriado.

c) Sabedoria de Salomão (LÍNDEZ, 2011, p. 231-258; CERESKO, 2004, p. 155-174).

Escrito originalmente em grego sob o título Sophia Salomonos, esse livro tem como autor um judeu da diáspora versado na língua grega, que assimilou a cultura helênica, suas formas literárias clássicas, suas ciências (7,17-20), o culto da beleza que lhe era característico (13,3.7), suas artes $(14,19)$ e até as disputas esportivas que eram comuns nessa cultura $(4,2 ; 10,12)$ etc.

Apesar de o autor demonstrar sentimentos benévolos para com os gentios, ele está solidamente ancorado na tradição religiosa de Israel. É um convicto monoteísta: tem horror ao politeísmo e à idolatria, despreza o laxismo e a imoralidade dos pagãos. Sente orgulho de pertencer ao povo eleito $(18,8)$, que segundo crê - recebeu as promessas do Deus único com o qual fez Aliança $(12,21)$. Por meio dessa Aliança, foi preservado da idolatria $(15,4)$ com o intuito de iluminar o mundo com sua Lei $(18,4)$. Dessa forma, para o autor, não obstante a cultura grega se sobressaísse pela variedade dos sistemas filosóficos e pela arte, a sabedoria 
de Israel era muito superior àquela, pois provém do Deus único e verdadeiro. Por esse motivo, segundo se pensava, os judeus não tinham motivos para invejar os gentios.

d) Obras de Fúlon de Alexandria (SKA, 2009, p. 44-48; COLLINS, 1983, p. 54-57).

Fílon viveu entre os anos 25 a.C. a 50 dC e pertence, em certo sentido, aos judeus historiadores helenistas. Foi um importante apologista do judaísmo frente à cultura grega, apresentando-o como uma tradição venerável da antiguidade. Para ele, o judaísmo, longe de ser um culto bárbaro de uma tribo nômade oriental, como pensavam alguns gregos, era uma antecipação dos princípios da filosofia helenista. O autor apresenta, através de metáforas, os costumes judaicos, considerados pelos gregos como primitivos ou exóticos. Fala da circuncisão do coração como o caminho da virtude, tema tão caro à filosofia grega, e da razão (logos) e da sabedoria (sophia) como emanações do Deus de Israel.

O Alexandrino assumiu a tarefa de mostrar como Deus tinha constituído o mundo material e espiritual através dos patriarcas e da Lei Mosaica (De Opificio Mundi; De Abrahamo e De Vita Mosis). Conforme Fílon, Abraão teria sido uma espécie de filósofo judeu alexandrino, muito diferente dos judeus de Israel, pois sua fidelidade não era primeiramente à Lei Mosaica, mas à Lei natural inscrita na consciência humana que, só posteriormente, fora descoberta pela contemplação filosófica.

Para mostrar a superioridade da sabedoria dos judeus, Fílon descreve a educação de Moisés. Seus instrutores egípcios teriam lhe ensinado aritmética, geometria e filosofia (De Vita Mosis I, 23-24), disciplinas que constituem a educação do rei-filósofo no livro $A$ República, de Platão. 
e) Obras de Flávio Josefo (SKA, 2009, p. 41-43; NICKELSBURG, 2011, p. 537-557).

O historiador judeu viveu entre os anos 37 a 100 dC. Relatou a destruição do templo de Jerusalém pelos romanos no ano 70 dC. Sua obra Antiguidades Judaicas, escrita com o objetivo de angariar o respeito dos eruditos romanos para com os judeus, é uma narrativa da história dos judeus desde o seu início até o tempo no qual viveu o autor.

Com finalidade apologética, Flávio Josefo consagra onze capítulos das Antiguidades Judaicas à figura de Abraão. Apresenta-o como um filósofo muito sábio. Para ele, o patriarca teria descoberto o monoteísmo contemplando os astros e seria, assim, o precursor das ciências, pois teria ensinado aos sábios do Egito a astrologia (astronomia) e a aritmética.

É notável o esforço desses escritores judeus para justificar a grandeza de suas tradições e personalidades. Não lhes faltam, porém, críticas acerca da negligência de alguns valores fundamentais da Lei de Moisés.

No dizer de Collins, por exemplo,

Os judeus apologetas como Filo e Josefo podiam se orgulhar da extensão da fama de Moisés, mas eram também prolixos em seus esforços para remover o escândalo de suas leis e reconciliá-las com a cultura helenística... [A lei mosaica] podia ser tratada seletivamente, ressaltando algumas leis e negligenciando outras, e podia ser reforçada com fundamentos filosóficos e religiosos, que estavam distantes da Torah original. (COLLINS, 1983, p. 137).

\subsection{Literatura de resistência}

Enquanto em Alexandria, os judeus viviam em paz e prosperavam produzindo seus textos e difundindo a cultura judaica por meio dos recursos helênicos, em Judá, em 198 a.C., deu-se início o domínio selêucida. A pior fase dessa dominação foi o período governado por Antíoco IV, cognominado Epífanes (187-175). Antíoco IV chegou ao poder após uma fase conturbada de dívidas com 
Roma, foi alvo de revoltas de seus súditos por causa de altos impostos e sobreviveu a assassinatos na disputa pela sucessão ao trono (COLLINS, 1983, p. 79-90).

Tendo assumido o poder, o novo soberano mostrou-se determinado a resgatar seu prestígio e a reafirmar os poderes militar, econômico e territorial de seu governo. Para fortalecer os laços políticos, religiosos e sociais, impôs aos judeus a religião e a cultura helênica, entrando em conflito violento com os anti-helênicos da Judeia.

Nessa época, novos textos foram acrescentados a alguns livros bíblicos com o objetivo de manter a fidelidade à Aliança, como é o caso do Livro de Zacarias. Quanto ao livro de Qohélet, também conhecido como Eclesiastes, há muita polêmica acerca de sua datação. Não há um consenso a esse respeito. Enquanto uns datam-no no final do império persa, outros o colocam no início da dominação grega. Seow (1996), depois de longa reflexão, dá ao livro a datação do final do império persa, embora o Eclesiastes conheça a filosofia grega - que já era bem difundida nessa ocasião. Daí sua ausência nessa lista aqui apresentada.

\section{a) Zacarias 9-11 (BOGGIO, 1995, p. 79-96)}

Escrito em hebraico, em Judá, sob a dominação selêucida, Zc 9-11 faz parte da literatura de resistência. Posteriormente foi anexado aos primeiros oito capítulos do livro de Zacarias, que ganhou seu formato final tal como o temos hoje. Os versículos 1 a 8 do capítulo 9 levam a pensar na campanha de Alexandre Magno na Síria e na terra de Israel em 332 a.C. Em Zc 9,3, aparece uma clara referência a uma rampa construída pelos soldados de Alexandre no cerco a Tiro e, em 9,13, os gregos são especificamente mencionados.

b) O livro de Baruc (BOGGIO, 1995, p. 135-150).

O personagem que dá nome ao livro é um suposto secretário do profeta Jeremias. Diante dos exilados na Babilônia, Baruc lê palavras encorajadoras. Ao ouvi-las, os deportados, arrependidos de suas culpas, choraram, oraram e 
jejuaram. Confessaram seus pecados e pediram a misericórdia do Senhor. Em seguida, o texto é enviado para ser lido em Jerusalém; há uma mensagem para os que estão no cativeiro, vendidos aos gentios. O livro termina com a Carta de Jeremias.

A exegese crítica, no entanto, rejeita Baruc como autor do livro e não aceita datar a obra no período babilônico. Há claros paralelos temáticos e linguísticos entre o livro de Baruc e algumas obras posteriores, como o livro de Daniel e o livro do Sirácida (Eclesiástico) que parecem confirmar essa suspeita.

Além disso, a menção ao dinheiro enviado pelos exilados para se oferecerem sacrifícios (1,6-14) dá a entender que o Templo fora reconstruído e que havia uma comunidade judaica próspera na Babilônia e isso não é possível no início do exílio, senão mais tardiamente. A restauração do culto no Templo de Jerusalém após sua profanação por Antíoco Epífanes parece ter fornecido o contexto histórico no qual o livro de Baruc foi escrito. As evidencias indicam a datação do livro entre 200-100 a.C.

c) O livro de Ester (NICKELSBURG, 2011, p. 387-391).

Essa obra, cujo acabamento foi dado por ocasião do período selêucida, exalta uma heroína judia que salva o povo da perseguição e que se deleita com a vitória judaica sobre o inimigo. A referência aos judeus dispersos (Est 3,8) denuncia um substrato do período grego. O enredo lembra ao povo fustigado pelas grandes potências da possibilidade sempre presente de perseguição por um tirano, não necessariamente um rei, mas por qualquer gentio que exercesse algum poder sobre eles. Os textos acrescentados a esse livro têm o objetivo de dar informações adicionais e maior enfoque ao drama interior vivenciado por Ester.

d) O livro de Daniel (NICKELSBURG, 2011, p. 162-173).

Apesar de essa obra ter sofrido acréscimos posteriores, ela surgiu no contexto da dominação helênica. Escrito por um grupo de judeus, em torno de um 
mestre do qual o livro recebeu o título, o livro de Daniel é o principal expoente de um tipo de literatura, a apocalíptica, que tem por objetivo a resistência contra a dominação estrangeira. O escrito surgiu por volta de 167-164 a.C., durante a perseguição de Antíoco Epífanes, mas esse acontecimento foi estrategicamente transportado para uma época anterior quando a Babilônia exercia seu domínio.

Como num filme de época, o autor transporta seus personagens para um tempo bem remoto ao qual o livro foi escrito. Com o pano de fundo do passado, fala de problemas de seu contexto e de seu tempo. A narrativa se passa na Babilônia, onde alguns jovens pertencentes a famílias nobres judaicas foram instruídos na sabedoria local, com o objetivo de servirem ao rei. O livro relata o episódio em que o monarca, tendo mandado fazer uma estátua de ouro, exigiu por parte dos dignitários do reino, que adorassem sua imagem na cerimônia de inauguração. Quatro jovens judeus se recusaram a prestar culto à estátua e foram lançados em uma fornalha ardente, mas saíram ilesos por causa da proteção divina (Dn 3,1-30).

Outro relato que denuncia os conflitos com Antíoco IV é o episódio no qual o rei decreta uma proibição de se adorar qualquer deus durante trinta dias. Daniel desobedece e é lançado na cova dos leões, mas estes nada lhe fazem. O rei fica pasmado diante do acontecido e exige que todos os súditos passem a adorar o Deus de Israel (Dn 6,2-29).

Enfim, o livro de Daniel é o expoente de uma literatura de resistência que visa manter a fé em momentos de grandes perseguições. A obra deseja incutir no leitor que, apesar de todas as dificuldades, quem é justo e reto sempre sairá ileso e o império opressor terá de reconhecer o poder de seu Deus. Tudo gira em torno da guerra entre o império opressor e o povo eleito, terminando com a vitória de Deus através de Israel sobre todas as nações da terra, quando se dará enfim a instauração do governo de Deus. 


\section{e) Os livros dos Macabeus}

Também os livros dos Macabeus se configuram como literatura de resistência ao helenismo. Esses escritos não sofreram acréscimos e tudo indica que não foram traduzidos do hebraico, tendo surgido originalmente em idioma grego. O Primeiro Livro dos Macabeus foi escrito, provavelmente, em torno do ano 100 a.C. e narra a campanha de Antíoco IV para impor a helenização sobre os judeus e a consequente sublevação daqueles que se mantinham fieis às tradições religiosas dos antepassados. Matatias e seus filhos se convertem nos agentes principais da unificação do povo em resistência contra os planos do dominador estrangeiro (NICKELSBURG, 2011, p. 209-215).

Ao contrário do que pode parecer inicialmente, o Segundo Livro dos Macabeus não é a continuação do Primeiro. Escrito entre os anos 125 e 63 a.C., o livro põe seu foco no Templo de Jerusalém sem, contudo, relatar a rebelião contra os gregos. Seu centro é a festa da Dedicação do Templo, instituída após sua restauração, e a interminável luta para manter pura a religião monoteísta.

\section{f) O livro de Judite (GERA, 2010, p. 29-36).}

A versão mais antiga do livro de Judite está na LXX. A pesquisa bíblica não fechou sua palavra acerca da língua original deste livro; não se sabe muito bem se é uma tradução do hebraico ou se foi escrito originalmente em grego. $\mathrm{O}$ livro de Judite não aparece mencionado em nenhuma literatura rabínica; o caráter impetuoso e sedutor da heroína parece escandalizar os escrúpulos dos rabinos.

Judite é uma obra de ficção histórica do tempo da opressão selêucida e usa referências deliberadamente anacrônicas e imprecisões históricas como uma referência a Nabucodonosor como rei da Assíria, que reinava em Nínive. Incorpora o gênero literário "tradições de salvação", muito comum no Antigo Testamento. O livro de Judite surge com base na história de Jael (Jz 4,17-24), que seduziu e embriagou o comandante cananeu Sísara antes de cravar a estaca da tenda na testa dele. A heroína Judite é um exemplo natural do paradoxo bíblico de "força na 
fraqueza”. Como sua precursora Jael, que enfrenta Sísara, e Judite, que enfrenta Holofernes, está equiparada a Davi, que enfrenta Golias. Trata-se de um relato heróico, cujos atos de extrema bravura salvaram o Povo da Aliança de um inimigo militarmente superior. Nabucodonosor, o grande rei opressor, de quem Holofernes é representante, simboliza os vários conquistadores da Judéia em diferentes períodos da história de Israel.

Como podemos observar, há duas posturas bem distintas dos judeus diante do helenismo: uma de acolhida da cultura helênica e sua defesa, outra de rejeição da mesma e de tudo que lhe diz respeito. A abertura e o fechamento ao helenismo estão diretamente relacionados com o contexto político, social e religioso no qual os judeus estavam imersos e no qual surgiram os escritos judaicos. Enquanto os judeus de Alexandria, que viviam em paz com os dominadores e prosperavam em terras estrangeiras, se mostravam favoráveis ao helenismo com a produção de uma literatura de justificação, os judeus da Terra de Israel, oprimidos pelo poder helênico exercido pelos Selêucidas, abominavam toda influência grega e deixavam registros de seus conflitos com essa cultura (literatura de resistência).

Da parte dos judeus de Alexandria, houve abertura ao universalismo, o que impunha um risco: a negligência de alguns valores fundamentais das tradições dos patriarcas presentes na Lei de Moisés. Da parte dos judeus estabelecidos em sua própria Terra, houve fechamento num nacionalismo exacerbado, com consequente valorização da identidade do povo da Aliança. Como afirma Collins, "a variedade do Judaísmo da Diáspora e seu peculiar caráter podem ser apreciados à luz dos modos como ele adaptou as leis tradicionais" (COLLINS, 1983, p. 137).

\section{Considerações finais}

Vários fatores favoreceram a mobilidade humana e a formação da Diáspora helenista, mas podemos dizer que o principal deles foi a inclusão do Mediterrâneo dentro das fronteiras de um único império com Alexandre Magno, como também a imposição do idioma grego sobre os povos conquistados. Isso oferecia 
oportunidades de viajar e negociar livremente ou mesmo mudar de domicílio, algo que jamais existira antes.

Apesar de a maioria dos gentios achar estranho o comportamento dos judeus na diáspora, muitos intelectuais estavam bem receptivos aos costumes religiosos e ao modo de vida judaicos. Alguns gentios chegaram a realizar algum tipo de conversão ao judaísmo. Por causa disso, foi muito importante a tradução das Escrituras para o grego e também de uma extensa produção literária, não apenas naquele idioma, mas influenciada pela cultura e pela filosofia gregas. Esse corpus literário fez com que a religião e os costumes judaicos fossem expressos através de outra cultura e outro idioma. Como se sabe, muitos são escritos apologéticos sobre a história e a religião judaica para ganhar a confiança dos governantes. Tinham o objetivo de permitir aos judeus viverem de acordo com os costumes de seus antepassados, além de convencer os gentios opositores e de procurar manter os judeus na fidelidade às suas raízes e identidades.

Feldman (1993, p. 124) divide as atitudes dos gentios em relação aos judeus em três grupos: negativa, neutra e positiva. Na antiguidade pagã, com alguma frequência, gentios escreveram positivamente sobre os judeus pelo mesmo motivo que outras pessoas escreveram negativamente sobre eles: os gentios pouco sabiam sobre o judaísmo. Josefo, por exemplo, tentou mudar essa situação apresentando uma descrição de Moisés que se diferenciava significativamente do modo como Moisés tinha sido representado na Bíblia Hebraica. O Moisés de Josefo se tornou compreensível para uma audiência pagã onde o Moisés bíblico nunca teria encontrado simpatia. Com seus escritos, Moisés passou a ser entendido pelos nãojudeus como algum tipo de filósofo e legislador que era comparável em estatura a Platão (cf. FELDMAN, p. 243-285). Em geral este era o objetivo geral da produção literária dos judeus da diáspora: tornar o judaísmo conhecido e compreendido pelos gentios. 
Quanto às atitudes negativas, estas se manifestaram, principalmente, na terra de Israel, por parte dos selêucidas. Em geral, os judeus continuavam sendo um povo exótico demais para os pagãos e estes usaram o poder político para tentar eliminar as tradições religiosas e o patrimônio cultural daqueles. Para os autores judeus, nessa situação a persistência do judaísmo representava um papel central e isso tornou-se o interesse da produção literária. Esse era o problema a ser resolvido para se chegar a uma definição adequada de sua própria identidade emtempos de perseguição. Os judeus não só tinham que explicar quem eles eram, mas também quem eles não eram, pois, para os pagãos, os judeus tinham se tornado um problema político.

O helenismo, representado pelos selêucidas, e o judaísmo da Judeia haviam se tornado culturas em confronto, cuja intensidade e alcance permaneceriam sem paralelo na história do povo da aliança. A literatura produzida naquela região ilustra bem isso. Judeus e gentios interagiram dentro do que se pode chamar de um fenômeno unidirecional de natureza essencialmente religiosa. Os não-judeus combatendo a religião judaica, e os judeus sendo imunes à influência estrangeira, helenista. Nesse sentido, os judeus que aderiram ao helenismo foram tratados como anti-heróis nas obras literárias daquele período.

Em contraste com a diáspora, onde se percebe que as comunidades judaicas foram profundamente helenizadas (cf. FELDMAN, p. 440), na Judeia, a influência da cultura grega sobre os judeus pode ser declarada mínima (cf. FELDMAN, p. 344).

Para os judeus da Judeia, se estes realmente interagissem com o helenismo, eles deixariam de ser estritamente ortodoxos e se tornariam assimilacionistas (cf. FELDMAN, p. 44). A questão, então, não é como os judeus e o judaísmo na terra de Israel foram helenizados, mas quão fortemente eles resistiram à helenização. 
Nossa principal conclusão é que os judeus da terra de Israel foram capazes não apenas de resistir às incursões culturais do helenismo, mas até mesmo de contra-atacar. Contudo, tanto na diáspora, quanto em Israel, o objetivo dos judeus foi alcançado somente por causa de sua produção literária. Foram os livros que os ajudaram a superar os desafios, e foi a posteridade quem ganhou com esse legado.

\section{REFERÊNCIAS}

BOGGIO, Giovanni. Joel, Baruc, Abdias, Ageu, Zacarias, Malaquias: os últimos profetas. São Paulo: Paulus, 1995.

CALABI, Francesca. História do Pensamento judaico-helenístico: com uma contribuição de Romano Penna sobre 'A literatura canônica do movimento cristão'. São Paulo: Loyola, 2013.

CERESKO, Anthony R. A sabedoria no Antigo Testamento: espiritualidade libertadora. São Paulo: Paulus, 2004.

CHEVITARESE, André Leonardo; CORNELLI, Gabriele. Judaísmo, cristianismo, helenismo: ensaios sobre interações culturais no Mediterrâneo antigo. Itu: Ottoni, 2003.

COHEN, Shaye J. D. The Beginnings of Jewishness: Boundaries, Varieties, Uncertainties. Hellenistic Culture and Society 31. Berkeley: University of California Press, 1999.

COLLINS, John J. Between Athens and Jerusalem: Jewish Identity in the Hellenistic Diaspora. New York: Crossroad, 1983.

DORIVAL, Gilles; Marguerite HARL; Olivier MUNNICH. La Bible grecque des Septante: du judaïsme hellénistique au christianisme ancien. Paris: Cerfs, 1988.

FELDMAN, Louis H. Jew and Gentile in the Ancient World: Attitudes and Interactions from Alexander to Justinian. Princeton: Princeton University, 1993.

GERA, Deborah Levine. The Jewish Textual Traditions. In Kevin R. Brine et al (Ed.). The Sword of Judith: Judith Studies Across the Disciplines. Cambridge: Open Book Publishers, 2010, p. 29-36.

HOLLAND, Tom. Fogo Persa: o primeiro império mundial e a batalha pelo Ocidente. Rio de Janeiro: Record, 2008. 
LEVINE, Amy-Jill. Diaspora as metaphor: Bodies and boundaries in the Book of Tobit. In: Diaspora Jews and Judaism: Essays in honor of, and in dialogue with, A. Thomas Kraabel. Florida: University of South Florida, 1992, p. 105-117.

LÍNDEZ, José Vílchez. Sabedoria e Sábios em Israel. São Paulo: Loyola, 2011. 2. ed.

NICKELSBURG, George W. E. Literatura Judaica entre a Bíblia e a Mixná: uma introdução histórica e literária. São Paulo: Paulus, 2011.

OTZEN, Benedikt. O Judaísmo na Antiguidade: A história política e as correntes religiosas de Alexandre Magno até o imperador Adriano. São Paulo: Paulinas, 2003.

RAINER, Kessler. História Social do Antigo Israel. São Paulo: Paulinas, 2009.

RAJAK, Tessa. Translation and Survival: The Greek Bible of the Ancient Jewish Diaspora. Oxford: Oxford University Press, 2009.

SEOW, Choon-Leong. Linguistic Evidence and the Dating of the Qohelet. Journal of Biblical Literature, v. 115, n. 4, p. 643-666, 1996.

SKA, Jean-Louis. Abraão e seus hóspedes: O patriarca e aqueles que creem no Deus único. São Paulo: Loyola, 2009. 